\title{
Comparative Study on Quality Parameters of Royal Jelly, Apilarnil and Queen Bee Larvae Triturate
}

\author{
Rodica MĂRGĂOAN ${ }^{1}$, Liviu Al. MĂRGHITAŞ², Daniel S. DEZMIREAN ${ }^{2}$, Otilia BOBIŞ², Victoriţa BONTA², \\ Corina CĂTANÄ $\breve{1}^{1}$, Adriana URCAN ${ }^{2}$, Carmen I. MUREŞAN ${ }^{2}$, Mirela G. MARGIN ${ }^{2}$ \\ ${ }^{1}$ Departament of Biodiversity, University of Agricultural Sciences and Veterinary Medicine Cluj- \\ Napoca, 3-5 Calea Mănăștur, 400372, Cluj-Napoca, Romania. \\ ${ }^{2}$ Department of Beekeeping and Sericulture, University of Agricultural Sciences and Veterinary \\ Medicine Cluj-Napoca, 3-5 Calea Mǎnăștur, 400372, Cluj-Napoca, Romania. \\ * corresponding author: ddezmirean@usamvcluj.ro \\ Bulletin UASVM Animal Science and Biotechnologies 74(1)/ 2017 \\ Print ISSN 1843-5262; Electronic ISSN 1843-536X \\ DOI:10.15835/buasvmcn-asb: 12622
}

\begin{abstract}
Given their beneficial effects in terms of health, the natural products, especially beehive products, have drawn the attention of consumers since long time ago. In order to guarantee the quality of these products on the market, their chemical composition needs to be analyzed. Thus, this current research had as objective the establishment of quality parameters for beehive brood food derived products: apilarnil and queen bee larvae triturate. These two products were compared with royal jelly which is the basis of brood food in the first 3 days of larval stage. The carbohydrates were determined by HPLC-IR and allowed the identification of seven carbohydrate compounds, predominantly glucose, fructose and sucrose. The lipid profile was analyzed by the Soxhlet method. The total protein content was determined by the Kjeldahl method. Free amino acids were analyzed by LC-MS. A total of 31 amino acids were identified of which nine are essential amino acids for humans.
\end{abstract}

Keywords: royal jelly, apilarnil, queen bee larvae, 10-HDA, amino acids

\section{INTRODUCTION}

Royal jelly (RJ) is a well-known beehive product with high nutritional values which promote human health thus it is used as a dietary supplement. It is a viscous secretion of the hypopharyngeal and mandibular glands of the young worker honeybees which take care of the brood in the hive. In their first 3 days all bee larvae are fed RJ and after this time point only the queen larvae receive exclusively RJ while the worker and drone larvae are fed with a modified food obtained from their glands secretion mixed with honey and pollen. Commercial RJ is obtained by harvesting the brood food from the queen cell in the 3rd day of larval development (ISO 12824:2016).
Diverse biological activities have been reported in the case of RJ: antibacterial (Fujivara et al., 1990; Fontana et al., 2004; Vezeteu et al., 2016), antiviral (Zhang et al., 2014) antitumor (Townsend et al., 1961), antioxidative (Nagai et al., 2001; Guo et al., 2009; Buratti et al., 2007; DelkhosheKasmaie et al., 2014; Malekinejad et al., 2016), anti-inflammatory (Fujii et al., 1990; Kohno et al., 2004), immunoregulatory (Okamoto et al., 2003; Vucevic et al., 2007), insulin-like (Dixit and Patel, 1964; Kramer et al., 1982), estrogen signaling mediating (Moutsatsou et al., 2010), antiaging (Inoue et al., 2003), reducing cholesterol levels (Kashima et al., 2014), vasodilation (Tokunaga et al., 2004). 
The drones represent the males of honeybees which emerge from unfertilized eggs while the workers and the queen who are the female individuals of honeybees develop from fertilized eggs.

Ilieșiu (1991) described the process for obtaining a beehive product which has increased biological activity due to the sum of nutritive compounds found both in the brood food and the body of the larvae. This product, named Apilarnil, is obtained after taking the whole composition of the 7-days-old drone larvae comb cells which are afterwards subjected to trituration, homogenization, filtration and lyophilization in order to have a safe and better preserved product. Queen bee larvae triturate is obtained in the same manner having as starting material the whole composition of queen bee larvae comb cells 1 day prior to capping. The whole content of the larvae cell after harvesting has an unctuous consistency which after trituration changes to a homogeneous milky appearance with a slightly gray yellowish color which tends to get brownish in time. In table 1 the values for the main compounds in these two products are listed.

The drone larvae contain testosterone, progesterone, prolactin and estradiol (Bogdanov, 2015). Recent studies showed both estrogenic (Mishima et al., 2005) and androgenic-like effect of drone food (Yucel et al., 2011). The androgenic- like effect seems to be related to the methyl palmitate and methyl oleate as active compounds found in the drone food (Seres et al.,2013). The drone larvae triturate (known as Apilarnil) is traditionally used for treating neuro vegetative and sexual problems (Bogdanov, 2011). A more recent research showed values of $20 \pm 2 \mu \mathrm{g} / \mathrm{g}$ of coenzyme Q-10 in drone homogenate and of $8 \pm$ $0.2 \mu \mathrm{g} / \mathrm{g}$ in RJ (Hryniewicka et al., 2016).

According to Ilieșiu (1991), in terms of organoleptic characteristics the product should have: viscous with fine granulation aspect, white with grey to brown shades colour, milky consistency and a characteristic brood food smell. Ilieșiu (1991) also analyzed the physico-chemical parameters for the obtained fresh Apilarnil (table 1).

In terms of chemical composition, there are various scientific articles and standards for RJ and Apilarnil, while for queen bee larvae triturate there is no literature data available until now, excepting a study from 2016 (Isidorov et al., 2016).

Amino acids have health-promoting effects and a recent study showed that the concentration of free amino acids in $\mathrm{RJ}$ is dependent on the time of harvest: the abundant free amino acids in RJ are proline, phenylalanine, lysine, glutamic acid and tyrosine and their concentration increases with increasing larval stage from $4,30 \mathrm{mg} / \mathrm{g}$ in the first day to $9,48 \mathrm{mg} / \mathrm{g}$ in the 3rd day of

Table1. The physico-chemical composition of fresh Apilarnil and fresh royal jelly according to different references

\begin{tabular}{|c|c|c|c|c|}
\hline & & Fresh Apilarnil & & Fresh royal jelly \\
\hline & $\begin{array}{c}\text { Ilieşiu, 1991; } \\
\text { Stângaciu, } 1999 \\
\end{array}$ & $\begin{array}{c}\text { Bărnuţiu et al., 2013; } \\
\text { Narumi et al., } 2004\end{array}$ & $\begin{array}{c}\text { Isidorov et al., } \\
2016\end{array}$ & Sabatini et al., 2009 \\
\hline $\mathrm{pH}$ & $4.8-6.7$ & & & $3.4-4.5$ \\
\hline Acidity & & 2.32 & & $3.0-6.0$ \\
\hline Water content (\%) & $65-75$ & 71.1 & 73.6 & $60-70$ \\
\hline Dry matter (\%) & $25-35$ & & & \\
\hline Ash (\%) & 2 & 0.9 & 0.7 & $0.8-3.0$ \\
\hline Proteins (\%) & $9-12$ & 7.23 & 10.0 & $9-18$ \\
\hline Lipids (\%) & $5-8$ & 3.80 & 3.5 & 3.8 \\
\hline 10-HDA (\%) & & & & $>1.4$ \\
\hline Carbohydrates (\%) & $6-10$ & & 12.2 & $7-18$ \\
\hline Glucose (\%) & $3.16-5$ & 3.61 & & $4-8$ \\
\hline Fructose (\%) & 0.03-0.5 & 0.60 & & $3-13$ \\
\hline Sucrose (\%) & $0.03-0.5$ & 0.14 & & $0.5-2.0$ \\
\hline
\end{tabular}


larval development (Jie et al., 2016). The major free amino acids found in RJ are proline, lysine, glutamate, $b$-alanine, phenylalanine, aspartate and serine and they have an average value of $7,3 \mathrm{mg} / \mathrm{g}$ (Boselli et al., 2003).

Apilarnil has various important amino acids like lisine, histidine, arginine, serine, glutamic acid, alanine, valine, methionine, isoleucine, leucine, tyrosine, fenilalanine according to Ilieşiu (1991). Apilarnil is used as a biostimulating product that is beneficial for the stomach ulcer and congestive liver (Bogdanov, 2012).

Recently, a study revealed that drone bee larvae homogenate contains about $20 \pm 2 \mu \mathrm{g} / \mathrm{g}$ coenzyme Q-10 (Hryniewicka et al., 2016). This fat-soluble molecule is involved in cellular energy production and antioxidant mechanisms. Apilarnil and queen bee larvae triturate are good candidates for getting the most out of the effects of coenzyme Q-10.

\section{MATERIALS AND METHODS}

The samples were obtained from a beekeeper in the spring of 2015. The samples were taken directly from the hive and stored at $-20{ }^{\circ} \mathrm{C}$ until further analysis.

Water content analysis was carried out by the gravimetric method according to Popescu and Meica (1997). The samples were dried in the oven at a temperature of $105^{\circ} \mathrm{C}$ until constant weight. The results were expresses as average percentage of three replicates \pm standard deviation.

Total proteins in the samples were determined by the Kjeldhal method according to AOAC. The samples were digested using Büchi Digestion Unit K-424 coupled with Büchi B-414 Scrubber. The distillation step was done using the KjelFlex K-360 device. The titration was performed using an automatic titrator Schott Titroline using sulfuric acid of $0.25 \mathrm{M}$ until a pH of 4.65 . The conversion factor of 6.25 was multiplied with the total nitrogen content determined by titration and the result was then the total protein in the sample.

Carbohydrates were analyzed by HPLC-IR using the optimized method of Sesta (2006). The samples were weighed and homogenized, then a mixture of ultrapure water and methanol $(\mathrm{v} / \mathrm{v}$ 3:1) was added, Carrez I and Carrez II reagent were used for precipitating the proteins. The centrifugation step was done at 4,000 rpm for 30 minutes. Afterwards the supernatant was washed with dichloromethane in order total extract the lipids and afterwards filtered (Millipore 0.45 $\mu \mathrm{m})$. The obtained filtrate was injected at a flow rate of $1 \mathrm{~mL} / \mathrm{min}$. and a $30^{\circ} \mathrm{C}$ temperature inside a VP HPLC with 100Ã Amino Altima column of $4.6 \mathrm{~mm}$ diameter, $250 \mathrm{~mm}$ length and $5 \mu \mathrm{m}$ particle size. For the calibration curve glucose, fructose, sucrose, maltose, turanose, trehalose, erlose and isomaltulose were used as standards. The carbohydrate values were expressed as percentage.

The lipids were determined by the Soxhlet method extraction using diethyl ether on a Soxtherm extraction unit. The lipid content was calculated as average percentage of three replicates.

The 10-hydroxy-2-decenoic acid (10-HDA) content was analyzed by HPLC-PDA using the modified method of Liu et al (2008). A mixture of ultrapure water and methanol of $\mathrm{pH} 2.5$ was used as mobile phase. The samples were weighed and dissolved in a mixture $(60: 40, \mathrm{v} / \mathrm{v})$ of methanol and ultrapure water of $\mathrm{pH} 2.5$ and then sonicated for 30 minutes. Mobile phase was added and then the samples were centrifuged at 4,000 rpm for 10 minutes and filtered ( $0.22 \mu \mathrm{m}$ filters). The analysis was done for a volume of injection of $20 \mu \mathrm{L}$ at a flow rate of $1 \mathrm{~mL} / \mathrm{min}$. and $40^{\circ} \mathrm{C}$ temperature inside a LC-10 AD VP (Shimadzu) using a reverse phase column LC-18 Supelcosil of $4.6 \mathrm{~mm}$ diameter, $250 \mathrm{~mm}$ length and $5 \mu \mathrm{m}$ particle size. The detection was at $210 \mathrm{~nm}$. For the calibration curve concentrations of the standard 10-HDA were in the range $0.2-200 \mu \mathrm{g} / \mathrm{ml}$ with a coefficient of determination of 0.9998 . The results of 10-HDA content were expressed as average percentage of three replicates.

The free amino acids were separated and quantified by LC-MS using a Shimadzu equipped with electrospray ionization spray and a positive mode of operation. The volume of injection was $1 \mu \mathrm{L}$ at a $35^{\circ} \mathrm{C}$ temperature inside a EZ: faast AAAMS, 250x3.0mm column. The mobile phases were $10 \mathrm{mM}$ ammonium formate in water and $10 \mathrm{mM}$ ammonium formate in methanol. The free amino acids were purified and extracted using the sample preparation method described in the EZ:faast Phenomenex kit. The values were expressed as $\mathrm{mg} / 100 \mathrm{~g}$. 


\section{RESULTS AND DISCUSSION}

Regarding the water content it can be stated that for RJ the results for this parameter were within the limits specified by the literature and standards. The quality standard proposed by Sabatini et al (2009) shows a water content percentage of 60$70 \%$ in fresh RJ. In our study the RJ samples had an average percentage of $66.03 \pm 0.03 \%$ which is in the range proposed. For Apilarnil the water content limits proposed by Ilieșiu (1991) are 65$75 \%$. The Apilarnil samples analyzed in our study had an average percentage of $73.25 \pm 0.02 \%$. The average percentage of water content in the bee queen larvae triturate was $75.17 \pm 0.15 \%$. For this parameter there is no information available in the literature for the queen bee larvae triturate.

Sabatini et al. (2009) established for protein content in RJ values of $9-18 \%$. The RJ samples under study had an average content of $11.14 \pm$ $0.11 \%$ which are within the limits proposed by the international standard. Ilieșiu (1991) determined for Apilarnil values of $9-12 \%$ protein content. The Apilarnil samples in our study had an average of $9.47 \pm 0.13 \%$ total proteins. The queen bee larvae triturate had an average of $12.03 \pm 0.05 \%$ total proteins which is superior to the protein content in RJ.

The identification and quantification of carbohydrate compounds was done in order to determine the quality and authenticity of the samples. In the RJ samples the three major carbohydrate compounds (glucose, fructose and sucrose) were identified along with the minore carbohydrate compounds like turanose, maltose, trehalose and erlose. The three major carbohydrate compounds account for $7-8 \%$ in $\mathrm{RJ}$ according to Sabatini et al. (2009). In the RJ samples studied the major carbohydrates had a mean value of $15.39 \pm 0.33 \%$. In the fresh Apilarnil samples, carbohydrates account for 6-10 \% according to Stangaciu (1999). In the Apilarnil samples analyzed in this study glucose, fructose, maltose and trehalose were identified but no sucrose was found. In queen bee larvae triturate the same three major carbohydrate compounds were found. In table 2 the average values for the determined carbohydrates are given in the analyzed samples.

Literature studies found in RJ the lipids content having values of 3-8\% (Sabatini et al., 2009). The RJ sample analyzed in our study had an average percentage of $3.96 \pm 0.09 \%$. For Apilarnil, Ilieșiu (1991) obtained a value of 5-8\%. Our samples had an average percentage of $8.38 \pm 0.16 \%$ total lipids. The queen bee larvae triturate presents an average percentage value of $10.30 \pm 1.74 \%$. No literature data for the lipid content in queen bee larvae triturate was found.

For the RJ samples, the lipidic compound 10HDA represents an authenticity marker as it can be found only in this product. Sabatini et al. (2009)

Table 2. Quality parameters as determined for royal jelly, Apilarnil and queen bee larvae triturate

\begin{tabular}{cccc}
\hline & RJ & $\begin{array}{c}\text { Queen bee larvae } \\
\text { triturate }\end{array}$ & Apilarnil \\
\hline Water content (\%) & $66.03 \pm 0.03$ & $75.17 \pm 0.15$ & $73.25 \pm 0.02$ \\
\hline Total proteins (\%) & $11.14 \pm 0.11$ & $12.03 \pm 0.05$ & $9.47 \pm 0.13$ \\
\hline Lipids (\%) & $3.96 \pm 0.09$ & $10.30 \pm 1.74$ & $8.38 \pm 0.16$ \\
\hline 10-HDA (\%) & $1.96 \pm 0.03$ & $0.09 \pm 0.01$ & - \\
\hline Carbohydrates (\%) & $15.39 \pm 0.33$ & & $0.38 \pm 0.01$ \\
\hline Fructose (\%) & $7.32 \pm 0.17$ & $1.25 \pm 0.08$ & $3.55 \pm 0.02$ \\
\hline Glucose (\%) & $7.37 \pm 0.15$ & $2.10 \pm 0.03$ & - \\
\hline Sucrose (\%) & $0.7 \pm 0.01$ & $0.08 \pm 0.01$ & - \\
\hline Turanose (\%) & $0.01 \pm 0.00$ & - & $0.9 \pm 0.05$ \\
\hline Maltose (\%) & $0.22 \pm 0.01$ & $0.78 \pm 0.02$ & - \\
\hline Trehalose (\%) & $0.03 \pm 0.01$ & $0.11 \pm 0.09$ & - \\
\hline Isomaltose (\%) & - & - & - \\
\hline Erlose (\%) & - & - & - \\
\hline Melesitose (\%) & - & &
\end{tabular}


gives a minimum level of $1.4 \%$ for RJ. The 10 -HDA level in the RJ samples analyzed in this study had an average value of $1.96 \pm 0.03 \%$. No 10-HDA was identified in Apilarnil while in the queen bee larvae triturate the average value was of $0.09 \pm 0.01 \%$.

A number of 31 free amino acids were identified in the analyzed samples (Table 3) from which nine essential amino acids can be found which cannot be synthesized de novo by human organism and thus must be supplied by diet.
This is a very important observation, taking into consideration that all three types of bee products that were analyzed, could be used as food supplements in human diet.

Royal jelly contains eight out of nine essential amino acids, tryptophan is missing from the composition, but this amino acid is needed in the smallest amount in the human diet, according to World Health Organization. The total amount of essential amino acids in royal jelly was 247.35

Table 3. Free amino acid content determined in royal jelly, apilarnil and queen bee triturate by LC-MS

\begin{tabular}{|c|c|c|c|}
\hline Amino acid & Royal Jelly (mg/100g) & $\begin{array}{l}\text { Queen bee larvae triturate } \\
(\mathrm{mg} / 100 \mathrm{~g})\end{array}$ & Apilarnil (mg/100g) \\
\hline Arginine (ARG) & 34.48 & 91.57 & 112.33 \\
\hline Glutamine (GLN) & 177.59 & - & - \\
\hline Serine (SER) & 2.72 & 105.70 & 86.84 \\
\hline Asparagine (ASN) & 2.91 & 81.11 & 77.36 \\
\hline Proline-hydroxyproline (PHP) & - & - & - \\
\hline 3-methyl histidine (3-MHIS) & 0.02 & - & - \\
\hline 1-methyl-histidine (1-MHIS) & 0.25 & 0.35 & 0.74 \\
\hline 4-hydroxyproline (HYP) & 2.28 & - & - \\
\hline Glycine (GLY) & 3.91 & 71.84 & 114.72 \\
\hline Glycine-proline (dipeptide) (GPR) & - & 1.53 & 1.16 \\
\hline Threonine (THR) & 1.99 & 72.52 & 122.69 \\
\hline Alanine (ALA) & 45.01 & 175.40 & 170.15 \\
\hline Gamma-aminobutyric acid (GABA) & 15.09 & 11.29 & 13.35 \\
\hline Sarcosine (SAR) & 2.96 & 11.47 & 6.72 \\
\hline Beta-aminoisobutyric acid ( $\beta$ AIBA) & 2.70 & 1.91 & 2.20 \\
\hline Alfa-aminobutyric acid (ABA) & 1.85 & 3.24 & 7.13 \\
\hline Ornithine (ORN) & 3.35 & 4.68 & 3.33 \\
\hline Methionine (MET) & 0.09 & 29.03 & 38.24 \\
\hline Proline (PRO) & 234.10 & 162.10 & 277.51 \\
\hline Lysine (LYS) & 221.07 & 201.28 & 120.79 \\
\hline Aspartic acid (ASP) & 27.30 & 69.37 & 8.51 \\
\hline Histidine (HIS) & 8.64 & 61.35 & 40.97 \\
\hline Valine (VAL) & 3.67 & 91.16 & 81.35 \\
\hline Glutamic acid (GLU) & 61.02 & 149.36 & 212.89 \\
\hline Tryptophan (TRP) & - & 38.40 & 32.41 \\
\hline Leucine (LEU) & 2.25 & 99.05 & 106.82 \\
\hline Phenylalanine (PHE) & 7.55 & 72.47 & 63.12 \\
\hline Isoleucine (ILE) & 2.09 & 36.58 & 49.47 \\
\hline Cystathionine (CTH) & - & 3.19 & 1.22 \\
\hline Cysteine (C-C) & - & 1.11 & 1.58 \\
\hline Tyrosine (TYR) & 2.50 & 133.43 & 76.55 \\
\hline Total essential amino acids & 247.35 & 701.84 & 655.86 \\
\hline Total free amino acids & 867.39 & 1780.67 & 1830.07 \\
\hline
\end{tabular}


$\mathrm{mg} / 100 \mathrm{~g}$. The highest amount of lysine is found in royal jelly $(221.07 \mathrm{mg} / 100 \mathrm{~g})$, this amino acid together with leucine are required in the highest amount in human diet, according to the same World Health Organization. Proline is a conditionally essential amino acid, meaning that its synthesis can be limited under special pathophysiological conditions, such as severe catabolic distress. Apilarnil has the highest content of proline from all the analyzed bee products ( $277.51 \mathrm{mg} / 100 \mathrm{~g})$, and for this reason this bee product is very important, as food supplement or ingredient in other type of natural supplements.

What is important to notice is that royal jelly is the only product where glutamine is found (177.59 mg/100g), another conditionally essential amino acid which is not found in queen bee larvae triturate and Apilarnil.

Queen bee triturate has a concentration of $701.84 \mathrm{mg} / 100 \mathrm{~g}$ essential amino acids (all nine) and $1780.67 \mathrm{mg} / 100 \mathrm{~g}$ total free amino acids. High amounts of non essential amino acids (the highest from the three bee products analyzed) were quantified in queen bee larvae triturate: $105.70 \mathrm{mg} / 100 \mathrm{~g}$ serine, $175.40 \mathrm{mg} / 100 \mathrm{~g}$ alanine, glutamic acid and also aspartic acid. From the essential amino acids present in this type of sample, highest amounts from all three types of analyzed bee products, were quantified as phenylalanine $(72.47 \mathrm{mg} / 100 \mathrm{~g})$, tryptophan $(38.40 \mathrm{mg} / 100 \mathrm{~g})$, valine $(91.16 \mathrm{mg} / 100 \mathrm{~g})$ and histidine $(61.35 \mathrm{mg} / 100 \mathrm{~g})$. Beside this valuable composition in essential amino acids, queen bee larvae triturate is valuable for its high content of tyrosine, a conditionally essential amino acid.

Although Apilarnil has the highest amount of free amino acids content from all three types of bee products $(1830.07 \mathrm{mg} / 100 \mathrm{~g})$, the amount of essential amino acids was lower compared to queen bee larvae triturate, meaning that non-essential amino acids and conditionally essential amino acids might be higher in quantity in the chemical composition of Apilarnil. Indeed, Apilarnil has the highest amount of proline $(277.51 \mathrm{mg} / 100 \mathrm{~g})$, arginine $(112.33 \mathrm{mg} / 100 \mathrm{~g})$ and glycine (114.72 $\mathrm{mg} / 100 \mathrm{~g})$.

What makes Apilarnil a valuable product from, is the high content of essential amino acids: threonine $(122,69 \mathrm{mg} / 100 \mathrm{~g})$, leucine (106.82 $\mathrm{mg} / 100 \mathrm{~g})$, isoleucine $(49.47 \mathrm{mg} / 100 \mathrm{~g})$ and methionine (38.24 mg/100 g). Comparing to royal jelly, the amount of threonine in Apilarnil is more than 100 times higher (122.69 versus $1.99 \mathrm{mg}$ ).

These last two bee products are not very known and studied, thus very few literature data regarding their chemical composition is existing at this time (Bărnuţiu et al., 2013, Andriţoiu et al., 2014, Isidorov et al., 2016), and this paper represent a step ahead in the characterization of these products.

\section{CONCLUSIONS}

Because insects are rich in proteins, lipids, carbohydrates, amino acids, vitamins and mineral elements they served and still do serve as food among some indigenous groups around the world. Thus edible insects have an important role in nutrition among people by supplementing the dietary needs and preventing malnutrition and other diseases.

This study showed that queen bee larvae triturate has high nutritive value when comparing with the other products analyzed. Queen bee larvae triturate has high lipid content, high protein content and high value of essential amino acids.

Information about the nutritive content of insect derived products is required in order to guarantee quality for consumers and provide the prospect for further exploitation for human health promoting food.

Therefore, the establishment of quality parameters for these brood food derived products makes possible the valorification in terms of nutritional and therapeutic value and contributes to the improved marketing of these products considering the increasing consumer demand for beneficial beehive products.

Aknowledgements: Financial support was granted by the project Partnerships in Priority Areas Programme - PN II, developed with the support of MEN - UEFISCDI, project no. 148/2014. The authors declare no conflict of interests.

\section{REFERENCES}

1. AOAC Kjeldahl method for proteins.

2. Andriţoiu CV, Ochiuz L, Andriţoiu V, Popa M, (2014). Effect of Apitherapy Formulations against Carbon TetrachlorideInduced Toxicity in Wistar Rats after Three Weeks of Treatment. Moleculers, 19, 13374-13391.

3. Bărnuțiu LI, Mărghitaș LA, Dezmirean DS, Bobiş O, Mihai C, Pavel C, (2013). Physicochemical composition of Apilarnil 
(bee drone larvae). Lucrări Ştiinţifice-Seria Zootehnie, 59, 199-202.

4. Bogdanov S, (2011). Royal Jelly, Bee Brood: Composition, Health, Medicine: A Review.

5. Bogdanov S, (2012). The Royal Jelly Book, Chapter II. In Bee Product Science.

6. Bogdanov S, (2015). Royal jelly, bee brood: composition, health, medicine: review. Bee Product Science, www.beehexagon.net. April

7. Boselli E, Fiorenza Caboni M, Sabatini AG, Marcazzan GL, Lercker G, (2003). Determination and changes of free amino acids in royal jelly during storage. Apidologie, 34(2): 129-137.

8. Buratti S, Benedetti S, Cosio M S, (2007). Evaluation of the antioxidant power of honey, propolis and royal jelly by amperometric flow injection analysis. Talanta, 71, 13871392.

9. Delkhoshe-Kasmaie F, Malekinejad H, Khoramjouy M, Rezaei-Golmisheh A, Janbaze-Acyabar H, (2014). Royal jelly protects from taxol-induced testicular damages via improvement of antioxidant status and up-regulation of E2f1. Systems Biology in Reproductive Medicine 60:8088.

10. Dixit PK, Patel NG, (1964). Insulin-like activity in larval foods of the honeybee. Nature, 202: 189-190.

11. Fontana R, Mendes MA, de Souza BM, Konno K, César LMM, Malaspina 0, Palma MS, (2004). Jelleines: a family of antimicrobial peptides from the Royal Jelly of honeybees (Apis mellifera). Peptides 25: 919-928.

12. Fujii A, Kobayashi S, Kuboyama N, Furukawa Y, Kaneko Y, Ishihara S, Yamamoto H, Tamura T, (1990). Augmentation of wound healing by royal jelly in streptozotocin-diabetic rats. Jpn J. Pharmacol. 53: 331-337.

13. Fujiwara S, Imai J, Fujiwara M, Yaeshima T, Kawashima T, Kobayashi K, (1990). Apotent antibacterial protein in royal jelly. J. Biol. Chem., 265: 11333-11337.

14. Guo H, Kouzuma Y, Yonekura M, (2009). Structures and properties of antioxidative peptides derived from royal jelly protein. Food Chemistry 113: 238-245.

15. Hryniewicka M, Karpinska A, Kijewska M, Turkowicz MJ, Karpinska J, (2016). LC-MS/MS analiysis of $\alpha$-tocopherol and coenzyme Q10 content in lyophilized royal gelly, beebread and drone homogenate. J of Mass Spectrometry 51:1023-1029.

16. Ilieşiu N V,(1991). Apilarnil, Editura Apimondia, Bucuresti.

17. Inoue S, Koya-Miyata S, Ushio S, Iwaki K, Ikeda $M$, Kurimoto M, (2003). Royal Jelly prolongs the life span of $\mathrm{C} 3 \mathrm{H} / \mathrm{HeJ}$ mice: correlation with reduced DNA damage. Experimental Gerontology 38: 965-969.

18. Isidorov VA, Bakier S, Stocki M, (2016). GC-MS Investigation of the chemical composition of honeybee drone and queen larva homogenate. J.Aoic. Sci. 60(1):11120.

19. ISO $12824: 2016$ Royal jelly — Specification

20. Jie H, Li PM, Zhao GJ, Feng XL, Zeng DJ, Zhang CL, Lei MY, Yu M, Chen $Q$, (2016). Amino acid composition of royal jelly harvested at different times after larval transfer. Genet Mol Res.;15(3), gmr.15038306.
21. Kashima Y, Kanematsu S, Asai S, Kusada M, Watanabe S, Kawashima T, Nakamura T, Shimada M, Goto T, Nagaoka S, (2014). Identification of a Novel Hypocholesterolemic Protein, Major Royal Jelly Protein 1, Derived from Royal Jelly. Plos One 9.

22. Kohno K, Okamoto I, Sano O, Arai N, Iwaki K, Ikeda M, and Kurimoto M, (2004). Royal jelly inhibits the production of proinflammatory cytokines by activated macrophages. Bioscience Biotechnology and Biochemistry 68: 138-145.

23. KRAMER KJ, Childs CN, Spiers RD, Jacobs RM, (1982). Purification of insulin-like peptides from insect haemolymph and royal jelly. Insect Biochem., 12(1):9198.

24. Liu JR, Yang YC, Shi LS, Peng C, (2008). Antioxidant Properties of Royal Jelly Associated wite Larval Age and Time of Harvest. J Agric Food Chem,56: 11447-52.

25. Malekinejad H, Ahsan S, Delkhosh-Kasmaie F, Cheraghi H, Rezaei-Golmisheh A, Janbaz-Acyabar H, (2016). Cardioprotective effect of royal jelly on paclitaxel-induced cardio-toxicity in rats. Iranian Journal of Basic Medical Sciences, 19(2): 221-227.

26. Mishima S, Suzuki KM, Isohama Y, Kuratsu N, Araki Y, Inoue M, Miyata T, (2005). Royal jelly has estrogenic effects in vitro and in vivo, Journal of Ethnopharmacology, 101: 215-220.

27. Moutsatsou P, Papoutsi Z, Kassi E, Heldring N, Zhao C, (2010). Fatty Acids Derived from Royal Jelly Are Modulators of Estrogen Receptor Functions. PLOS ONE 5(12), e15594

28. Nagai T, Sakaia M, Inouec R, Inouec H, Suzukia N, (2001). Antioxidative activities of some commercially honeys, royal jelly, and propolis. Food Chem., 75, 237-240.

29. Narumi S. (2004). Honeybee brood as a nutritional food. Mitsubachi Kagaku (Honeybee Science), 25: 119-124.

30. Okamoto I, Taniguchi Y, Kunikita T, Kohno K, Iwaki K, Ikeda M, (2003). Major royal jelly protein 3 modulates immune responses in vitro and in vivo. Life Sci., 1, 2029-2045.

31. Popescu M, Meica S, (1997). Produsele apicole şi analiza lor chimică, Ed. Diaconu Coresi, București.

32. Sabatini A G, Marcazzan GL, . Caboni MF, Bogdanov S, Bicudo de Almeida-Muradiana L, (2009). Quality and standardisation of Royal Jelly. Journal of ApiProduct and ApiMedical Science 1(1): 1-6.

33. Seres AB, Ducza E, Bathori M, Hunyadi A, Beni Z, Dekany M, Gaspar R, (2013). Raw drone milk of honeybees elicits uterotrophic effect in rats: evidence for estrogenic activity. Journal of Medicinal Food, 16: 404-409.

34. Sesta G, (2006). Determination of sugars in royal jelly by HPLC. Apidologie 37: 84-90.

35. Stângaciu S, (1999). Apiterapy course notes. Constanţa Apiterapy Research Hospital, București. Romania.

36. Tokunaga KH, Yoshida C, Suzuki KM, Maruyama H, Futamura Y, Araki Y, Mishima S, (2004). Antihypertensive effect of peptides from Royal Jelly in spontaneously hypertensive rats. Biological \& Pharmaceutical Bulletin 27: 189-192.

37. Townsend GF, Brown WH, Felauer EE, Hazlett B, (1961). Studies on the in vitro antitumor activity of fatty acids. 
IV. The esters of acids closely related to 10-hydroxy-2decenoic acids from royal jelly against transplantable mouse leukemia. Can. J. Biochem. 39: 1765-70.

38. Vezeteu TV, Bobiş O, Moritz RF, Buttstedt A, (2016). Food to some, poison to others - honeybee royal jelly and its growth inhibiting effect on European Foulbrood bacteria. MicrobiologyOpen1-7

39. Vucevic D, Melliou E, Vasilijic S, Gasic S, Ivanovski P, Chinou I, Colic M, (2007). Fatty acids isolated from royal jelly modulate dendritic cell-mediated immune response in vitro. Int. Immunopharmacol., 7: 1211-1220.
40. Yucel B, Acikgoz Z, Bayraktar H, Seremet C, (2011). The Effects of Apilarnil (Drone Bee Larvae) Administration on Growth Performance and Secondary Sex Characteristics of Male Broilers, Journal of Animal and Veterinary Advances, 10 (17): 2263-2266.

41. Zhang Y, Zhang G, Huang X, Han R, (2014). Proteomic analysis of Apis cerana and Apis mellifera larvae fed with heterospecific royal jelly and by CSBV challenge. PLoS ONE 9, e102663. 